\title{
Model Trade-Off Likuiditas dan Profitabilitas dalam Manajemen Modal Kerja pada Perusahaan Ritel yang Tercatat di Bursa Efek Indonesia (BEI)
}

\author{
Nourma Juwita \\ STIE Muhammadiyah Jakarta, nourma.juwita@yahoo.com \\ Heri Ispriyahadi \\ STIE Muhammadiyah Jakarta, h.ispriyahadi@yahoo.com
}

\begin{abstract}
Abstrak
Penelitian ini bertujuan untuk memberikan gambaran tingkat modal kerja, likuiditas, dan profitabilitas, serta mengetahui proporsi modal kerja yang efisien pada perusahaan ritel yang terdaftar di Bursa Efek Indonesia tahun 2009-2013. Aplikasi model trade-off dilakukan dengan menggunakan persamaan goal programming model yang terdiri dari rasio target dan batasan tiap variabel. Rasio target mencakup current ratio, working capital turnover ratio, fixed assets turnover ratio, dan profit margin. Variabel-variabel yang dimaksud meliputi cash, marketable securities, account receivable, inventory, current liabilities, fixed assets, sales, dan profit. Hasil penelitian menunjukkan bahwa terdapat 6 perusahaan ritel yang sudah menggunakan modal kerja secara efisien dibanding rata-rata industri, dengan menghasilkan opportunity loss bernilai negatif. Terdapat 7 perusahaan ritel masih kurang efisien dalam menggunakan modal kerjanya dengan menghasilkan opportunity loss positif. Penelitian ini juga memberikan rekomendasi terhadap masing-masing perusahaan terkait proporsi modal kerja yang sesuai dengan target industri.

Kata Kunci : Model Trade-off, Modal Kerja, Likuiditas, Profitabilitas, Perusahaan Ritel
\end{abstract}

\section{PENDAHULUAN}

Dengan dibukanya pintu masuk bagi para peritel asing sebagaimana Keputusan Presiden No. 118 tahun 2000 yang telah mengeluarkan bisnis ritel dari negative list bagi penanaman modal asing (PMA), sejak itu ritel asing mulai marak masuk ke Indonesia. Menjamurnya bis- nis ritel dalam waktu sepuluh tahun bela- kangan membuat perusahaan harus dapat me- ngelola manajemen modal kerjanya untuk da- pat memberikan profit yang optimal bagi per- usahaan. Dalam menentukan operasional per- usahaan, likuiditas sangat penting bagi suatu perusahaan, hal ini berkaitan dengan berhasil tidaknya suatu perusahaan dikelola. Likuiditas yang baik pada perusahaan menyangkut perse- diaan kebutuhan dana, baik sumber dana tunai maupun sumber dana nontunai untuk meme- nuhi kebutuhan atau membayar kewajiban jangka pendek. Dengan demikian untuk perusahaan yang bergerak pada bidang usaha dagang atau industri sebaiknya memperhati- kan adanya tingkat likuiditas. Hal ini dikare- nakan jika likuiditas terlalu tinggi akan ber- akibat pada profitabilitas yang diperoleh oleh perusahaan.

Dalam menentukan kebijakan modal kerja yang efisien, perusahaan dihadapkan pada masalah adanya tradeoff. Sehubung dengan hal tersebut, perusahaan sebaiknya menentu- kan proporsi antara likuiditas modal kerja agar mendapatkan profitabilitas yang optimal. Mo- dal kerja memiliki sifat yang fleksibel. Besar kecilnya modal kerja dapat ditambah atau dikurangi sesuai kebutuhan perusahaan. Be- sarnya modal kerja harus sesuai dengan ke- butuhan perusahaan, karena baik kelebihan (over-emphasis) atau kekurangan (under-em- phasis) modal kerja keduanya akan membawa dampak negatif bagi perusahaan. Pengelolaan modal kerja yang baik ber- tujuan untuk memenuhi operasi perusahaan sehari-hari, misalkan untuk membayar gaji pegawai, pembelian bahan baku dan lain seba- gainya, dimana dana yang telah dikeluarkan diharapkan akan dapat kembali lagi masuk ke dalam perusahaan dalam waktu yang pendek melalui hasil penjualan produksinya. 
Profit pada perusahaan merupakan indikator perusa- haan dapat mengelola sumber daya dengan baik. Untuk itu, dalam penerapan model trade off likuditas dan profitabilitas dilakukan seba- ik mungkin untuk menghasilkan modal kerja perusahaan yang lebih efisien dalam peneri- maan profit pada kelompok perusahaan ritel.

Model trade off likuiditas dan profita- bilitas dalam pengelolaan modal kerja sangat penting untuk dikaji, sebab dengan penetuan model yang tepat dapat membuat perusahaan memperoleh laba yang optimal. Aktiva lancar harus cukup besar untuk dapat menutup hutang jangka pendek perusahaan, sehingga menggambarkan adanya tingkat keamanan (margin safety) yang memuaskan. Sementara itu, jika perusahaan menetapkan modal kerja yang berlebih akan menyebabkan perusahaan overliquid sehingga menimbulkan dana yang menganggur dan akhirnya mengakibatkan mo- dal kerja tidak efisien serta membuang kesem- patan memperoleh laba yang optimal.

Untuk itu dalam penelitian ini rumusan masalah yang akan di kaji adalah :

a. Bagaimana tingkat modal kerja perusahaan ritel di Indonesia?

b. Bagaimana tingkat likuiditas perusahaan ritel di Indonesia?

c. Bagaimana tingkat profitabilitas perusahaan ritel di Indonesia?

d. Bagaimana memperoleh formula antara likuiditas dan profitabilitas agar mem- peroleh hasil yang optimal pada perusahaan ritel Indonesia? profitabilitas agar memperoleh hasil yang optimal. Dan sebagai bahan masukan kepada perusahaan dalam memberikan solusi dari permasalahan tentang likuiditas dan profitabilitas yang optimal dalam mencapai modal kerja yang efisien, serta dapat dijadikan sebagai benchmark memutuskan kebijakan modal kerja yang efisien pada perusahaan ritel dengan periode waktu yang sama.

\section{KAJIAN LITERATUR}

Likuiditas merupakan salah satu komponen keuangan yang penting untuk dianalisis. Likuiditas adalah salah satu alat untuk mengukur keberhasilan perusahaan dari segi kemampuan perusahaan memenuhi kewajiban lancar. Untuk mengetahui tingkat likuiditas perusahaan, dapat dilakukan dengan menghitung rasio likuiditas. Rasio ini membandingkan kewajiban jangka pendek dengan sumber daya jangka pendek yang tersedia untuk memenuhi kewajiban tersebut (Horne dan Wachowicz, 2009: 206). Adapun rasio likuiditas yang sering digunakan adalah current ratio. Menurut Gitman (2006: 58), tingkat likuiditas dapat dihitung dengan membagi nilai aset lancar perusahaan dengan kewajiban lancarnya. Current Ratio merupa- kan perbandingan antara jumlah aktiva lancar yang dimiliki perusahaan dengan hutang jangka pendek. Rumus yang digunakan adalah sebagai berikut: Menurut Horne dan WachowiczPenelitian trade off likuiditas dan profitabilitas dalam manajemen modal kerja pada perusahaan ritel bertujuan untuk menentukan formula antara likuiditas dan (2009:222), rasio profitabilitas merupakan rasio yang menghubungkan laba dari penjualan dan investasi. Rasio profitabilitas mengukur tingkat kinerja keuangan dari suatu per- usahaan. Profitabilitas memberikan gambaran seberapa efektif perusahaan beroperasi sehing- ga memberikan keuntungan bagi perusahaan. Profitabilitas merupakan salah satu rasio keuangan yang menunjukkan perbandingan antara laba dengan aktiva atau modal. Untuk mengukur profitabilitas sering digunakan indikator return on asset, return on equity, net profit margin. Setiap perusahaan selalu membutuhkan gramming solution. Prioritas utamanya difo- kuskan pada likuiditas, dengan menargetkan current ratio dan quick ratio model. Hal ini bertujuan untuk mengoptimalkan likuiditas dan profitabilitas. Secara khusus, jika pro- fitabilitas berkurang maka hal ini dapat me- nangkap kesempatan biaya kelebihan likui- ditas dan sebaliknya. Dalam model yang diterapkan Agar wal (1998) tersebut digunakan sejumlah variabel keputusan yang mencangkup komponen modal kerja, diantaranya adalah cash, marketable securities, account receiv- able, inventory, current liabilities, fixed asset, sales dan profit. modal kerja untuk membelanjai operasi sehari-hari dimana uang atau dana yang telah dikeluarkan, diharapkan akan dapat kembali lagi masuk dalam perusahaan melalui penju- alan. Dana masuk yang berasal dari penjualan tersebut akan segera dikeluarkan lagi untuk membiayai operasional selanjutnya, dengan demikian maka dana tersebut akan terus me- nerus berputar setiap periodenya selama per- usahaan beroperasi. Hubungan antara modal kerja dengan penjualan disebut juga rasio perputaran modal kerja 
(working capital turnover). Working capital turnover digu- nakan untuk mengukur keefektifan pendayagunaan modal kerja untuk melaksanakan ke- giatan perusahaan dan menunjukkan banyak- nya penjualan yang dapat diperoleh perusa- haan untuk tiap rupiah modal kerja (Munawir, 2004:80). Untuk menghitung rasio working capital turnover sebagai berikut :

Menurut Dash dan Hanuman (2009), mo- del yang dirumuskan oleh Agarwal memiliki beberapa keterbatasan. Model Agarwal terlalu menekankan target likuiditas pada formulanya. Rasio likuiditas diberikan pada likuiditas serta pada sub-target yang meliputi aset lancar dan kewajiban lancar. Selain itu, pada profitability goal yang dirumuskan Agarwal ditemukan persamaan yang masih ambigu. Variabel profit ternyata tidak dihubungkan dengan variabel-variabel modal kerja. Dash dan Hanuman (2009), mencoba memperbaiki keterbatasan-keterbatasan model yang dirumuskan oleh Agarwal. Dash dan Hanuman mencoba menghubungkan antara variabel profit dengan variabel-variabel modal kerja.

\section{KAJIAN TEORI}

Likuiditas merupakan salah satu komponen keuangan yang penting untuk dianalisis. Likuiditas adalah salah satu alat untuk mengukur keberhasilan perusahaan dari segi kemampuan perusahaan memenuhi kewajiban lancar. Untuk mengetahui tingkat likuiditas perusahaan, dapat dilakukan dengan menghitung rasio likuiditas. Rasio ini membandingkan kewajiban jangka pendek dengan sumber daya jangka pendek yang tersedia untuk memenuhi kewajiban tersebut (Horne dan Wachowicz, 2009: 206). Adapun rasio likuiditas yang sering digunakan adalah current ratio. Menurut Gitman (2006: 58), tingkat likuiditas dapat dihitung dengan membagi nilai aset lancar perusahaan dengan kewajiban lancarnya. Current Ratio merupa- kan perbandingan antara jumlah aktiva lancar yang dimiliki perusahaan dengan hutang jangka pendek. Rumus yang digunakan adalah sebagai berikut: Menurut Horne dan WachowiczPenelitian trade off likuiditas dan profitabilitas dalam manajemen modal kerja pada perusahaan ritel bertujuan untuk menentukan formula antara likuiditas dan (2009:222), rasio profitabilitas merupakan rasio yang menghubungkan laba dari penjualan dan investasi. Rasio profitabilitas mengukur tingkat kinerja keuangan dari suatu per- usahaan. Profitabilitas memberikan gambaran seberapa efektif perusahaan beroperasi sehing- ga memberikan keuntungan bagi perusahaan. Profitabilitas merupakan salah satu rasio keuangan yang menunjukkan perbandingan antara laba dengan aktiva atau modal. Untuk mengukur profitabilitas sering digunakan indikator return on asset, return on equity, net profit margin. Setiap perusahaan selalu membutuhkan gramming solution. Prioritas utamanya difo- kuskan pada likuiditas, dengan menargetkan current ratio dan quick ratio model. Hal ini bertujuan untuk mengoptimalkan likuiditas dan profitabilitas. Secara khusus, jika pro- fitabilitas berkurang maka hal ini dapat me- nangkap kesempatan biaya kelebihan likui- ditas dan sebaliknya. Dalam model yang dite- rapkan Agarwal (1998) tersebut digunakan se- jumlah variabel keputusan yang mencangkup komponen modal kerja, diantaranya adalah cash, marketable securities, account receiv- able, inventory, current liabilities, fixed asset, sales dan profit. modal kerja untuk membelanjai operasi sehari-hari dimana uang atau dana yang telah dikeluarkan, diharapkan akan dapat kembali lagi masuk dalam perusahaan melalui penju- alan. Dana masuk yang berasal dari penjualan tersebut akan segera dikeluarkan lagi untuk membiayai operasional selanjutnya, dengan demikian maka dana tersebut akan terus me- nerus berputar setiap periodenya selama per- usahaan beroperasi. Hubungan antara modal kerja dengan penjualan disebut juga rasio perputaran modal kerja (working capital turnover). Working capital turnover digu- nakan untuk mengukur keefektifan pendayagunaan modal kerja untuk melaksanakan ke- giatan perusahaan dan menunjukkan banyak- nya penjualan yang dapat diperoleh perusa- haan untuk tiap rupiah modal kerja (Munawir, 2004:80). Untuk menghitung rasio working capital turnover sebagai berikut :

Menurut Dash dan Hanuman (2009), mo- del yang dirumuskan oleh Agarwal memiliki beberapa keterbatasan. Model Agarwal terlalu menekankan target likuiditas pada formulanya. Rasio likuiditas diberikan pada likuiditas serta pada sub-target yang meliputi aset lancar dan kewajiban lancar. Selain itu, pada profitability goal yang dirumuskan Agarwal ditemukan persamaan yang masih ambigu. Variabel profit ternyata tidak dihubungkan dengan variabel-variabel modal kerja. Dash dan Hanuman (2009), mencoba memperbaiki 
keterbatasan-keterbatasan model yang dirumuskan oleh Agarwal. Dash dan Hanuman mencoba menghubungkan antara variabel profit dengan variabel-variabel modal kerja.

\section{Penelitian Terdahulu}

Beberapa penelitian dinegara lain telah mencoba menganalisa mengenai trade off likuiditas dan profitabilitas. Diantaranya March Deloof (2003) menemukan hubungan dan pengaruh modal kerja terhadap profitabilitas di Belgia, yakni para manager Penelitian ini berupaya menerapkan model trade-off likuiditas dan profitabilitas yang dirumuskan oleh Agarwal (1998) dan telah dikembangkan oleh Dash dan Hanuman (2009). Agarwal (1998) merumuskan tentang keputusan modal kerja sebagai goal pro-dapat meningkatkan profitabilitas dengan mengurangi number of days account receivables dan inventories. Ioannis Lazaridis dan Msc Dimitrios Tryfonidis (2004), hasil penelitian menemukan bahwa secara statistik manajemen modal kerja memiliki pengaruh negatif yang signifikan terhadap profitabilitas perusahaan-perusahaan non-finansial di Athens.

Selain itu,penelitian mengani pengaruh likuiditas dan profitabilitas juga dilakukan oleh Abdul Raheman dan Mohamed Nasr (2007) bahwa terdapat pengaruh negatif yang kuat antara komponen working capital terhadap profitabilitas perusahaan. Hubungan negatif yang signifikan antara utang yang digunakan oleh perusahaan dan profitabilitas. Penelitian juga menemukan ada hubungan positif antara ukuran perusahaan dan profitabilitas. Penelitian yang dilakukan Rathiranee Yogendrarajah (2012) menemukan hubungan positif antara profitabilitas dengan manajemen modal kerja dan struktur biaya. Profitabilitas menentukan bagaimana manajer atau pemilik akan bertindak dalam hal pengelolaan modal kerja perusahaan. Penurunan laba dikaitkan dengan number of days dari hutang. Perusahaan akan rugi jika menunggu lebih lama untuk membayar ta- gihan mereka dari jangka waktu kredit yang diberikan oleh supplier. Hubungan negatif an- tara piutang dan profitabilitas perusahaan me- nunjukkan bahwa perusahaan rugi dan akan menurunkan piutang mereka.

Ashok Kumar Panigrahi (2013). Hasil penelitian menunjukkan bahwa meskipun ada hubungan positif antara modal kerja dan pro- fitabilitas, namun tidak berlaku untuk semua kasus. Perusahaan yang menghasilkan keun- tungan yang baik dengan modal kerja negatif maupun perusahaan tidak mampu mengha- silkan keuntungan yang baik bahkan dengan memiliki modal kerja yang positif. Namun, dapat dikatakan bahwa modal kerja negatif menunjukkan non-likuiditas atau kurang li- kuid dalam perusahaan tidak diinginkan pada setiap tahapan bisnis.

Penelitian ini merujuk pada penelitian yang dilakukan oleh Dash dan Hanuman tahun 2009 yang berjudul "A Liquidity-Profitability Trade-off Model for Working Capital Mana- gement" dengan subjek penelitian perusahaan Vijaya Krishna Spice Farms Pvt Ltd. India, yang bergerak pada pengolahan makanan. Pada penelitian tersebut Dash dan Hanuman (2009) menganalisis data keuangan perusa- haan periode tahun 20042009. Peneliti akan melakukan langkah yang dilakukan Dash dan Hanuman yakni dengan menetapkan tingkat current ratio, working capital turnover ratio, fixed assets turnover ratio, dan net profit margin perusahaan dari rata-rata selama lima tahun (2009-2013).

Dash dan Hanuman (2009) menggunakan konsep model Agarwal yang telah direvisi dengan menambah beberapa batasan-batasan yang tidak diterangkan dalam model Agarwal sebelumnya. Hal ini bertujuan untuk menghi- tung tingkat optimal dari profitabilitas dan likuiditas perusahaan tersebut agar modal kerja lebih efisien. Solusi yang diperoleh un- tuk mendapatkan tingkat modal kerja yang efisien dibatasi oleh sejumlah variabel kons- train yang dirumuskan dalam goal pro- gramming model. Selain itu, dari analisis sensitifitas terdapat urutan variabel konstrain dari yang paling berpengaruh terhadap tingkat modal kerja.

Pada perusahaan yang diteliti, berdasar- kan analisis sensitivitas (sensitivity analysis) terdapat urutan elastisitas dari yang paling sensitif adalah sebagai berikut:
a. Piutang (Accounts receivable)
b. Persediaan (Inventory)
c. Kewajiban lancar (Current liabilities)
d. Surat berharga (Marketable securities)
e. Aset tetap (Fixed assets), dan 


\section{f. Kas (Cash).}

Perubahan tingkat piutang perusahaan ternyata memiliki sensitifitas yang paling tinggi terhadap target laba yang diusulkan. Sedangkan perubahan tingkat kas pada perusahaan tersebut mempunyai sensitifitasyang paling rendah terhadap target laba baru yang diusulkan.

Pada penelitian ini, penulis juga menerap- kan model trade-off yang dirumuskan oleh Dash dan Hanuman (2009) untuk mengana- lisis kondisi modal kerja perusahaan ritel yang menjadi sampel. Dengan menggunakan model trade-off tersebut dapat diketahui proporsi antara likuiditas dan profitabilitas yang optimal bagi tiap perusahaan ritel. Selan- jutnya, dengan membandingkan solusi dari hasil trade-off model yang diterapkan pada skala industri dengan proporsi modal kerja awal yang telah digunakan oleh tiap perusahaan ritel tersebut.

\section{METODE}

Jenis penelitian yang diterapkan dalam penelitian ini adalah penelitian deskriptif dan aplikatif. Dalam menentukan trade off likuiditas dan profitabilitas modal kerja yang efisien dilakukan dengan menerapkan goal programming model. Formulasi goal programming setiap target dimasukkan dalam kendala-kendala persamaan. Fungsi kendala semacam ini disebut sebagai kendala tujuan (goal constraint), dimana didalam persama- annya telah melibatkan deviasi, $d+$ dan $d$ - dimana dalam program linier kedua peubah tersebut adalah slek dan surplus. Populasi dalam penelitian ini adalah seluruh perusahaan ritel yang terdaftar di Bursa Efek Indonesia tahun 2009-2013. Jumlah populasi dalam penelitian ini adalah sebanyak 22 perusa- haan. Sumber data untuk penelitian ini menggunakan sumber data sekunder. Untuk memperoleh data yang diperlukan dalam penelitian ini, penulis menggunakan teknik dokumentasi dengan melihat laporan ke- uangan perusahaan sampel. Dengan teknik ini penulis mengumpulkan data laporan keuangan perusahaan dari tahun 2009 sampai 2013 mengenai variabel yang akan diteliti yaitu Profitabilitas, Likuiditas dan Modal Kerja.

TABEL 1.1

\section{Variabel dan Target Parameter}

\begin{tabular}{|l|c|c|}
\hline \multicolumn{1}{|c|}{$\begin{array}{c}\text { Variab } \\
\text { el }\end{array}$} & $\begin{array}{c}\text { Simb } \\
\text { ol }\end{array}$ & $\begin{array}{c}\text { Targe } \\
\text { t }\end{array}$ \\
\hline Cash & $\mathrm{X}_{1}$ & $\mathrm{C}$ \\
\hline Marketable Securities & $\mathrm{X}_{2}$ & $\mathrm{MS}$ \\
\hline Account Receivable & $\mathrm{X}_{3}$ & $\mathrm{AR}$ \\
\hline Inventory & $\mathrm{X}_{4}$ & $\mathrm{I}$ \\
\hline Current Liabilities & $\mathrm{X}_{5}$ & $\mathrm{CL}$ \\
\hline Fixed Assets & $\mathrm{X}_{\mathrm{f}}$ & $\mathrm{FA}$ \\
\hline Sales & $\mathrm{Y}$ & $\mathrm{S}$ \\
\hline Net Profit & $\Pi$ & $\mathrm{P}$ \\
\hline Current Ratio & & $\Theta$ \\
\hline $\begin{array}{l}\text { Working Capital } \\
\text { Turnover } \\
\text { Ratio }\end{array}$ & & $\omega$ \\
\hline $\begin{array}{l}\text { Fixed Assets Turnover } \\
\text { Ratio }\end{array}$ & & $\Phi$ \\
\hline Profit Margin & & $\mathrm{M}$ \\
\hline
\end{tabular}

Sumber : Dash dan Hanuman (2009)

Setelah menentukan target pada tiap variabel, selanjutnya diberikan tingkat prioritas dan deviasi yang berbeda pada masing-masing target solusi yang diinginkan. 
TABEL 1.2

Tingkat Prioritas untuk Setiap Batasan Fungsi Objektif

\begin{tabular}{|c|c|c|}
\hline Variable & Priority & $\begin{array}{l}\text { Deviation } \\
\text { Variables }\end{array}$ \\
\hline Liquidity & P1 & $\mathrm{d} 1^{-}, \mathrm{d} 1^{+}$ \\
\hline $\begin{array}{l}\text { Working Cap } \\
\text { Turnover }\end{array}$ & P2 & $\mathrm{d} 2^{-}, \mathrm{d} 2^{+}$ \\
\hline $\begin{array}{l}\text { Fixed assets } \\
\text { Turnover }\end{array}$ & P3 & $d 3^{-}, \mathrm{d}^{+}$ \\
\hline Profit Margin & $\mathrm{P} 4$ & $\mathrm{~d} 4^{-}, \mathrm{d} 4^{+}$ \\
\hline Opportunity Cost & P5 & $d 5^{-}, \mathrm{d} 5^{+}$ \\
\hline Cash & P6 & $d 6^{-}, \mathrm{d} 6^{+}$ \\
\hline Marketable Securities & P7 & $d 7^{-}, \mathrm{d} 7^{+}$ \\
\hline Accounts receivable & P8 & $\mathrm{d} 8^{-}, \mathrm{d}^{+}$ \\
\hline Inventories & P9 & $d 9^{-}, \mathrm{d} 9^{+}$ \\
\hline Current liabilities & P10 & d10-,d10+ \\
\hline Fixed assets & $\mathrm{P} 11$ & $\mathrm{~d} 11^{-}, \mathrm{d} 11^{+}$ \\
\hline Sales & P12 & $\mathrm{d} 12^{-}, \mathrm{d} 12^{+}$ \\
\hline Profit & P13 & d13 $3^{-}, \mathrm{d}^{+} 3^{+}$ \\
\hline
\end{tabular}

Sumber : Dash dan Hanuman (2009)

Tabel 1.3 Rumus Fungsi Liner

Goal Programming Model

$\Sigma$

\begin{tabular}{|c|c|c|}
\hline No. & Constraints & Functions \\
\hline 1 & Total assets & $\begin{array}{r}x_{1}+x_{2}+x_{3}+x_{4}-x_{5}+ \\
x_{f}=C+M S+A R+I \\
-C L+F A\end{array}$ \\
\hline 2 & Liquidity & $\begin{aligned} \mathrm{x}_{1}+\mathrm{x}_{2}+\mathrm{x}_{3}+\mathrm{x}_{4}+\mathrm{d}_{1}^{-} \\
-\mathrm{d}_{1}^{+}=\Theta . \mathrm{CL}\end{aligned}$ \\
\hline 3 & $\begin{array}{l}\text { Working Capital } \\
\text { Turnover }\end{array}$ & $\begin{array}{r}y-w\left(x_{1}+x_{2}+x_{3}+\right. \\
\left.x_{4}-x_{5}\right)+d_{2}^{-}-d_{2}^{+}=0\end{array}$ \\
\hline 4 & $\begin{array}{l}\text { Fixed Assets } \\
\text { Turnover }\end{array}$ & $y-\Phi \cdot x_{f}+d_{3}^{-}-d_{3}^{+}=0$ \\
\hline 5 & Profit Margin & $\pi-M \cdot y+d_{4}^{-}-d_{4}^{+}=0$ \\
\hline 6 & Opportunity Cost & $\begin{array}{r}\pi-\mathrm{M} . \Phi\left(\mathrm{x}_{1}+\mathrm{X}_{2}+\mathrm{X}_{3}\right. \\
\left.+\mathrm{x}_{4}-\mathrm{x}_{5}-\mathrm{y} / \omega\right)+\mathrm{d}_{5}^{--} \\
\mathrm{d}_{5}^{+}=\mathrm{P}\end{array}$ \\
\hline 7 & Cash & $x_{1}+d_{6}^{-}-d_{6}^{+}=C$ \\
\hline 8 & $\begin{array}{l}\text { Marketable } \\
\text { Securities }\end{array}$ & $\mathrm{x}_{2}+\mathrm{d}_{7}^{-}-\mathrm{d}_{7}^{+}=\mathrm{MS}$ \\
\hline 9 & $\begin{array}{l}\text { Accounts } \\
\text { Receivable }\end{array}$ & $x_{3}+d_{8}^{-}-d_{8}^{+}=A R$ \\
\hline 10 & Inventories & $\mathrm{X}_{4}+\mathrm{d}_{9}^{-}-\mathrm{d}_{9}^{+}=1$ \\
\hline 11 & Current Liabilities & $x_{5}+d_{0}^{-}-d_{10}^{+}=C L$ \\
\hline
\end{tabular}




\begin{tabular}{|r|l|r|}
\hline 12 & Fixed assets & $\mathrm{Xf}_{\mathrm{f}}+\mathrm{q}_{1}^{-}-\mathrm{d}_{11}^{+}=\mathrm{FA}$ \\
\hline 13 & Sales & $\mathrm{y}+\mathrm{q}_{2}^{-}-\mathrm{d}_{12}^{+}=\mathrm{S}$ \\
\hline 14 & Net Profit & $\pi+\mathrm{d}_{13}-\mathrm{d}_{13}{ }^{+}=\mathrm{P}$ \\
\hline
\end{tabular}

Sumber : Dash dan Hanuman (2009)

Tabel 1.4

Kriteria Pemilihan Sampel

\begin{tabular}{|l|c|}
\hline \multicolumn{1}{|c|}{ Kriteria Sampel } & $\begin{array}{c}\text { Jumlah } \\
\text { Perusahaan }\end{array}$ \\
\hline $\begin{array}{l}\text { Jumlah perusahaan ritel yang } \\
\text { tercatat di BEI }\end{array}$ & 22 \\
\hline $\begin{array}{l}\text { Perusahaan yang tidak go public } \\
\text { dari tahun 2009-2013 }\end{array}$ & 8 \\
\hline $\begin{array}{l}\text { Laporan keuangan dengan mata } \\
\text { uang selain rupiah }\end{array}$ & 1 \\
\hline Jumlah sampel yang digunakan & 13 \\
\hline
\end{tabular}

Sumber : Publikasi laporan keuangan perusahaan yang diolah (2015)

\section{HASIL DAN PEMBAHASAN}

Modal kerja (working capital) yang digunakan oleh setiap perusahaan ritel pada tahun 2009 hingga 2013 sangat bervariasi begitu juga perputaran dari modal kerja tersebut. Modal kerja berfungsi sebagai kekuatan perusahaan untuk membelanjai kegiatan opeasi sehari- hari, seperti pembiayaan utang jangka pendek. Tabel 1.5 menyajikan rincian tingkat modal kerja yang digunakan oleh setiap perusahaan ritel tersebut.

\section{Tabel 1.5}

\section{Working Capital Perusahaan Ritel Th 2009-2013 (Juta Rupiah)}

\begin{tabular}{|c|c|c|c|c|c|}
\hline $\begin{array}{c}\text { Kode } \\
\text { Perusahaan }\end{array}$ & $\begin{array}{c}\text { Current } \\
\text { Liabilities } \\
\text { (1) }\end{array}$ & $\begin{array}{l}\text { Current Asset } \\
\text { (2) }\end{array}$ & $\begin{array}{l}\text { Working Capinal } \\
\text { (2)-(1) }=(3)\end{array}$ & $\begin{array}{l}\text { Sales } \\
\text { (4) }\end{array}$ & $\begin{array}{l}\text { Working Capital } \\
\text { Turnover Ratio } \\
(4)+(3)=(5)\end{array}$ \\
\hline ACES & 199.510 & 1.090 .167 & 890.657 & 2.509 .014 & 2,82 \\
\hline AMRT & 3.918 .983 & 3.215 .264 & (703.718) & 20.221 .861 & $(28,74)$ \\
\hline CENT & 67.834 & 116.343 & 48.509 & 38.930 & 0,80 \\
\hline CSAP & 1.373 .520 & 1.561 .600 & 188.080 & 4.327 .804 & 23,01 \\
\hline HERO & 2.219 .961 & 2.061 .943 & (158.019) & 9.136 .710 & $(57,82)$ \\
\hline KOIN & 316.146 & 359.154 & 43.008 & 809.398 & 18.82 \\
\hline LPPF & 1.683 .230 & 1.473 .596 & (209.634) & 4.356 .649 & $(20,78)$ \\
\hline MAPI & 2.338 .949 & 2.760 .078 & 421.128 & 6.406 .769 & 15,21 \\
\hline MPPA & 2.984 .553 & 4.665 .128 & 1.680 .575 & 10.102 .955 & 6,01 \\
\hline RALS & 784.468 & 2.105 .285 & 1.320 .817 & 5.174 .450 & 3,92 \\
\hline RIMO & 5.806 & 3.174 & (2.632) & 19.375 & $(7,36)$ \\
\hline SONA & 198.440 & 456.138 & 257.698 & 747.923 & 2,90 \\
\hline TRIO & 2.860 .131 & 4.351 .766 & 1.491 .635 & 7.955 .372 & 5,33 \\
\hline Industri & 1.457 .810 & 1.863 .049 & 405.239 & 5.523 .632 & 13.63 \\
\hline
\end{tabular}

Sumber : Laporan keuangan setiap perusahaan yang diolah (2015)

Berdasarkan data tersebut di atas perusa- haan PT Matahari Putra Prima Tbk (MPPA), mempunya tingkat modal kerja sebesar Rp1,6 triliun, jauh di atas rata-rata industri sebesar Rp405 miliar. PT Matahari Putra Prima Tbk (MPPA) memiliki rasio perputaran modal kerja terhadap total penjualan yang telah diperolehnya 6,01 kali, jauh di bawah target rata-rata rasio perputaran modal kerja industri sebesar 13,63 kali. PT Hero Supermarket Tbk (HERO) mencatatkan tingkat modal kerja sebesar minus -Rp158 miliar (dengan kata lain perusahaan tersebut menggunakan hutang sebagai modal kerjanya), yakni lebih kecil daripada modal kerja 
industri yang ditargetkan yakni Rp 405milar. PT Hero Supermarket Tbk (HERO) mampu memperoleh rasio perputaran modal kerja sebesar 57,82 kali.

Jika dibandingkan dengan PT Hero Supermarket Tbk (HERO), maka modal kerjayang digunakan oleh PT Matahari Putra Prima Tbk (MPPA) kurang efektif. Hal ini dapat tercermin pada jumlah modal kerja yang digunakan oleh PT Matahari Putra Prima Tbk (MPPA) jauh lebih besar daripada PT Hero Supermarket Tbk (HERO). Akan tetapi rasio perputaran modal kerja yang digunakan PT Matahari Putra Prima Tbk (MPPA), jauh lebih kecil daripada rasio perputaran modal kerja yang digunakan PT Hero Supermarket Tbk (HERO).

Di sisi lain, PT Sumber Alfaria Trijaya Tbk (AMRT) mencatatkan jumlah modal kerja bernilai minus sebesar minus -Rp703,7 miliar (menggunakan hutang sebagai modal kerjanya). Modal kerja yang dicatatkan oleh PT Sumber Alfaria Trijaya Tbk (AMRT) tersebut jauh lebih kecil dibandikan rata-rata modal kerja industri yang ditargetkan. Dengan bermodal hutang sebesar yang dicatatkan tersebut, PT Sumber Alfaria Trijaya Tbk (AMRT) mampu menghasilkan jumlah penjualan sebesar Rp20,22 triliun sehingga rasio perputaran modal kerja terhadap penjualannya sebesar 28,74 kali.

Dilihat dari perbandingan tingkat rasio perputaran modal kerjanya serta perolehan jumlah masing-masing perusahaan ritel terhadap rata-rata industri yang ditargetkan seperti terlihat pada Tabel 1.5 di atas, PT Hero Supermarket Tbk (HERO) memiliki modal kerja yang paling efektif, namun demikian PT Hero Supermarket Tbk (HERO) juga harus diperhatikan dalam sisi penggunaan hutang perusahaan.Perusahaan harus berhati-hati dalam penggunaan sumber dana yang berasal dari hutang, agar tidak menimbulkan kesulitan likuiditas jangka panjang,dalam artian perusahaan tidak mampu memenuhi kewa- jiban pada waktunya. Hal ini dapat dihindari dengan cara menjaga likuiditas perusahaan sehingga seluruh kewajiban yang sudah jatuh tempodapat terpenuhi.

Fixed Asset Turnover Perusahaan Ritel Rasio ini bergunauntuk mengevaluasi kemampuan perusahaan menggunakan aktiva- nya secara efektif untuk meningkatkan penda- patan. Jika perputarannya lambat (rendah),kemungkinan terdapat kapasitas terlalu besar atau ada banyak aktiva tetap namun kurang bermanfaat, atau mungkin disebabkan hal-hal lain seperti investasi pada aktiva tetap yang berlebihan dibandingkan dengan nilai output yang akan diperoleh. Jadi semakin tinggi rasio ini berarti semakin efektif penggunaan aktiva tetap tersebut.

Perputaran asset tetap yang digunakan oleh setiap perusahaan ritel pada tahun 2009 hingga 2013 sangat bervariasi. Tabel 1.6 dihalam berikutnya menyajikan rincian tingkat fixed asset turnover yang digunakan oleh setiap perusahaan ritel tersebut.

\section{Tabel 1.6}

\section{Fixed Asset Turnover Ratio Perusahaan Ritel Tahun 2009-2013 (Juta Rupiah)}

\begin{tabular}{crrr}
\hline $\begin{array}{c}\text { Kode } \\
\text { Perusahaan }\end{array}$ & \multicolumn{1}{c}{ Sales } & Fixed Assets & \multicolumn{1}{c}{ FA Ratio } \\
& \multicolumn{1}{c}{ (1) } & \multicolumn{1}{c}{ (2) } & $(\mathbf{1})+(\mathbf{2})=(\mathbf{3})$ \\
\hline ACES & 2.509 .014 & 511.728 & 4,90 \\
AMRT & 20.221 .861 & 2.905 .618 & 6,96 \\
CENT & 38.930 & 178.813 & 0,22 \\
CSAP & 4.327 .804 & 582.358 & 7,43 \\
HERO & 9.136 .710 & 2.480 .113 & 3,68 \\
KOIN & 809.398 & 45.885 & 17,64 \\
LPPF & 4.356 .649 & 938.020 & 4,64 \\
MAPI & 6.406 .769 & 2.292 .747 & 2,79 \\
MPPA & 10.102 .955 & 4.753 .599 & 2,13 \\
RALS & 5.174 .450 & 1.675 .946 & 3,09 \\
RIMO & 19.375 & 8.229 & 2,35 \\
SONA & 747.923 & 279.854 & 2,67 \\
TRIO & 7.955 .372 & 171.443 & 46.40 \\
Industri & 5.523 .632 & 1.330 .186 & 4,15 \\
\hline Sumber : Laporan keuangan setiap perusahaan yang diolah $(2015)$.
\end{tabular}

Berdasarkan data pada Tabel 1.6, PT Trikomsel Oke Tbk (TRIO) memperoleh hasil tertinggi dibandingkan dengan perusahaan lain, yakni sebesar 46,4 , jauh di bawah target rata-rata rasio perputaran aktiva tetap industri sebesar 4,15 kali. Hal ini berartibanyaknya penjualan yang dapat diperoleh perusahaan sebesar 46,4 kali dari total aset tetapnya. Sedangkan PT Centrin Online Tbk (CENT) yakni sebesar 0,22 kali, jauh di bawah 
target rata-rata rasio perputaran aktiva tetap industri sebesar 4,15 kali. Hal ini berarti banyaknya penjualan yang dapat diperoleh perusahaan sebesar 0,22 kali dari total aset tetapnya.

\section{Likuiditas Perusahaan Ritel}

Tingkat kecukupan dana yang digunakan setiap perusahaan ritel untuk kebutuhan kewajiban lancarnya juga sangat bervariasi. Pada perusahaan ritel likuiditas menentukan bahwa perusahaan itu dapat mengelola dananya dengan baik. Perusahaan yang mampu memenuhi kewajiban keuangannya secara tepat waktu, berarti perusahaan tersebut dapat dikatakan berada dalam keadaan yang likuid.

Dasar perbandingan dengan mengguna- kan current ratio menunjukan apakah jumlah aktiva lancar itu cukup melampaui besarnya kewajiban lancar, sehingga dapatlah kiranya diperkirakan bahwa sekiranya pada suatu ketika dilakukan likuiditas dari aktiva lancar dan ternyata hasilnya di bawah nilai dari yang tercantum di neraca, namun masih tetap akan terdapat cukup kas ataupun yang dapat dikonversikan menjadi uang kas di dalam waktu singkat, sehingga dapat memenuhi kewajibannya. Tingkat likuiditas dari setiap perusahaan dapat tercermin pada nilai current ratio. Tingkat current ratio untuk setiap perusahaan ritel yang menjadi sampel penelitian dapat dilihat pada Tabel 1.7 .

PT Ace Hardware Indonesia Tbk (ACES) mempunyai tingkat rasio lancar sebesar 5,46 kali, jauh di atas dari rata-rata rasio lancar industri yang ditargetkan yaitu 1,28 kali. Jika dibandingkan dengan target industri, aset lancar perusahaan tersebut dapat dikatakan over-liquid. Hal ini berarti dana menganggur yang dicatatkan perusahaan tersebut cukup besar.

Sebaliknya, perolehan tingkat rasio lancar yang dicatatkan oleh PT Rimo Catur Lestari Tbk (RIMO) jauh di bawah target industri. Perusahaan tersebut mencatatkan rasio lancar sebesar 0,55 kali. Jika dibandingkan dengan target industri, maka rasio lancar perusahaan tersebut dapat dikatakan under-liquid. Hal ini mengindikasikan bahwa aktiva lancar yang dimiliki untuk membiayai kewajiban lancar perusahaan kekurangan, yang berpotensi dapat menganggu operasional perusahaan.

Tabel 1.7

\section{Likuiditas (Liquidity) Perusahaan Ritel Tahun 2009-2013 (Juta Rupiah)}

\begin{tabular}{crrr}
\hline $\begin{array}{c}\text { Kode } \\
\text { Perusahaan }\end{array}$ & $\begin{array}{c}\text { Current } \\
\text { Liabilities }\end{array}$ & Current Asset & Curent Ratio \\
\hline (1) & \multicolumn{1}{c}{$(\mathbf{2})$} & $(\mathbf{2}) \div(\mathbf{1})=(\mathbf{3})$ \\
\hline ACES & 199.510 & 1.090 .167 & 5,46 \\
AMRT & 3.918 .983 & 3.215 .264 & 0,82 \\
CENT & 67.834 & 116.343 & 1,72 \\
CSAP & 1.373 .520 & 1.561 .600 & 1,14 \\
HERO & 2.219 .961 & 2.061 .943 & 0,93 \\
KOIN & 316.146 & 359.154 & 1,14 \\
LPPF & 1.683 .230 & 1.473 .596 & 0,88 \\
MAPI & 2.338 .949 & 2.760 .078 & 1,18 \\
MPPA & 2.984 .553 & 4.665 .128 & 1,56 \\
RALS & 784.468 & 2.105 .285 & 2,68 \\
RIMO & 5.806 & 3.174 & 0,55 \\
SONA & 198.440 & 456.138 & 2,30 \\
TRIO & 2.860 .131 & 4.351 .766 & 1,52 \\
Industri & 1.457 .810 & 1.863 .049 & 1,28 \\
\hline Sumber : Laporan keuangan setiap perusahaan yang diolah (2015)
\end{tabular}

\section{Profitabilitas Perusahaan Ritel}

Tingkat profitabilitas dari setiap perusahaan ritel yang menjadi sampel dalam penelitian ini dapat tercermin pada nilai profit margin. Hubungan antara laba dan penjualan menunjukkan kemampuan manajemen dalam menjalankan perusahaan secara cukup berhasil untuk menyisakan margin tertentu sebagai kompensasi yang wajar bagi pemilik yang telah menyediakan modalnya untuk suatu risiko. 
Perusahaan retail tidak akan berjalan tanpa adanya sistem penjualan yang baik. Penjualan merupakan ujung tombak dari sebuah perusahaan. Sistem persaingan juga membuat produksi serta konsumsi sumber daya alam, sumber daya manusia dan modal yang dimiliki perusahaan dituntut untuk menjadi lebih efisien. Akibat dari persaingan ini banyak perusahaan yang mengalami guncangan hebat, ini diakibatkan karena selain perusahaan tidak bias bersaing dengan perusahaan lain tetapi perusahaan tidak dapat meningkatkan keuntungan perusahaan atau bahkan perusahaan mengalami kerugian. Para investor pasar modal perlu mengetahui kemampuan perusahaan untuk menghasilkan laba. Dengan mengetahui hal tersebut investor dapat menilai apakah perusahaan itu profitabel atau tidak. Tabel 1.8 di bawah ini memperlihatkan tingkat profit margin dari setiap perusahaan ritel dari tahun 2009-2013.

\section{Tabel 1.8}

\section{Profitabilitas (Profitability) Perusahaan Ritel Tahun 2009-2013 (Juta Rupiah)}

\begin{tabular}{|c|c|c|c|}
\hline \multirow{2}{*}{$\begin{array}{c}\text { Kode } \\
\text { Perusahaan }\end{array}$} & Sales & Profit & Profit Margin \\
\hline & (1) & (2) & $(2) \div(1)=(3)$ \\
\hline ACES & 2.509 .014 & 398.278 & 0,16 \\
\hline AMRT & 20.221 .861 & 513.961 & 0,03 \\
\hline CENT & 38.930 & (10.168) & $(0,26)$ \\
\hline CSAP & 4.327 .804 & 117.000 & 0,03 \\
\hline HERO & 9.136 .710 & 436.088 & 0,05 \\
\hline KOIN & 809.398 & 2.776 & 0,00 \\
\hline LPPF & 4.356 .649 & 486.111 & 0,11 \\
\hline MAPI & 6.406 .769 & 375.555 & 0,06 \\
\hline MPPA & 10.102 .955 & 312.135 & 0,03 \\
\hline RALS & 5.174 .450 & 392.877 & 0,08 \\
\hline RIMO & 19.375 & 6.512 & 0,34 \\
\hline SONA & 747.923 & 105.242 & 0,14 \\
\hline TRIO & 7.955 .372 & 647.512 & 0,08 \\
\hline Industri & 5.523 .632 & 291.068 & 0,05 \\
\hline
\end{tabular}

Tingkat profit margin yang dicatatkan PT Centrin Online Tbk(CENT) berada di bawah rata-rata industri yang diusulkan selama periode 2009-2013 sebesar 0,05 atau 5\%. Perusahaan tersebut mencatatkan tingkat rugi bersih sebesar $-0,26 \%$ dari total penjualannya (profit margin sebesar $-26 \%$ ). Berdasarkan rata-rata profit margin industri, perusahaan tersebut memiliki tingkat profitabilitas paling kecil dibandingkanperusahaan ritel lainnya bahkan minus atau rugi.

Hasil yang berbeda dicatatkan oleh PT Rimo Catur Lestari Tbk (RIMO). Walaupun perusahaan tersebut membukukan tingkat likuiditas di bawah rata-rata industri bahkan paling kecil (lihat Tabel 1.5), tetapi tingkat profitabilitasnya jauh di atas dari rata-rata industri. Tingkat profit margin yang diperoleh sebesar 0,34 atau $34 \%$ jauh lebih tinggi dari rata-rata industri sebesar 0,05 atau 5\%.Berdasarkan rata-rata profit margin industri, perusahaan tersebut memiliki tingkat profitabilitas paling tinggi dibandingkan perusahaan ritel lainnya. 


\section{Tabel 1.9}

Data Rata-Rata Laporan Keuangan Perusahaan Ritel Selama Tahun 2009-2013 (Juta Rupiah)

\begin{tabular}{crrrrrrrr}
\hline Kode Industri & Cash & $\begin{array}{c}\text { Marketable } \\
\text { Securities }\end{array}$ & $\begin{array}{c}\text { Account } \\
\text { Receivable }\end{array}$ & Inventory & $\begin{array}{c}\text { Current } \\
\text { Liabilities }\end{array}$ & Fixed Assets & \multicolumn{1}{c}{ Sales } & Profit \\
\hline ACES & 13.232 & 293.828 & 34.090 & 450.695 & 199.510 & 511.728 & 2.509 .014 & 398.278 \\
AMRT & 207.530 & 380.264 & 479.491 & 3.345 .239 & 3.918 .983 & 2.905 .618 & 20.221 .861 & 513.961 \\
CENT & 26.300 & 26.224 & 12.462 & 273 & 67.834 & 178.813 & 38.930 & $(10.168)$ \\
CSAP & 7.266 & 43.551 & 644.602 & 1.951 .384 & 1.373 .520 & 582.358 & 4.327 .804 & 117.000 \\
HER0 & 81.126 & 300.830 & 194.083 & 1.268 .717 & 2.219 .961 & 2.480 .113 & 9.136 .710 & 436.088 \\
KOIN & 144 & 14.303 & 179.670 & 431.007 & 316.146 & 45.885 & 809.398 & 2.776 \\
LPPF & 801.465 & 832.700 & 49.981 & 1.607 .473 & 1.683 .230 & 938.020 & 4.356 .649 & 486.111 \\
MAPI & 319.492 & 354.228 & 267.119 & 1.691 .412 & 2.338 .949 & 2.292 .747 & 6.406 .769 & 375.555 \\
MPPA & 24.308 & 2.993 .996 & 270.121 & 1.470 .352 & 2.984 .553 & 4.753 .599 & 10.102 .955 & 312.135 \\
RALS & 19.307 & 864.109 & 17.979 & 744.352 & 784.468 & 1.675 .946 & 5.174 .450 & 392.877 \\
RIM0 & 190 & 2227 & 93 & 176 & 5.806 & 8.229 & 19.375 & 6.512 \\
SONA & 4.847 & 238.027 & 26.033 & 163.526 & 198.440 & 279.854 & 747.923 & 105.242 \\
TRI0 & 244.710 & 242.548 & 1.277 .870 & 4.393 .303 & 2.860 .131 & 171.443 & 7.955 .372 & 647.512 \\
Industri & 134.609 & 506.526 & 265.661 & 1.347 .531 & 1.457 .810 & 1.294 .181 & 5.523 .632 & 291.068 \\
\hline Sumber : Pengolahan data & & & & & &
\end{tabular}

Tabel 1.10

Solusi untuk Tahun 2009-2013 (Juta Rupiah)

\begin{tabular}{|c|c|c|c|c|c|c|c|c|c|}
\hline Kode Industri & Cash & $\begin{array}{l}\text { Marketable } \\
\text { Securities }\end{array}$ & $\begin{array}{l}\text { Account } \\
\text { Receivable }\end{array}$ & Invertory & $\begin{array}{l}\text { Curremt } \\
\text { Liabilities }\end{array}$ & Fixed Assets & Sales & Profit & $\begin{array}{c}\text { Opportunity } \\
\text { Cost } \\
\end{array}$ \\
\hline ACES & 13.232 & 293.828 & 34.090 & 698,435 & 199.510 & 263.988 & 755.942 & 39.834 & $(358.444)$ \\
\hline AMRT & 207.530 & 380.264 & 479.491 & 1.065 .324 & 3.918 .983 & 5.185 .533 & 14.848 .997 & 782.468 & 268.506 \\
\hline CENT & 26.300 & 26.224 & 12.462 & 89.329 & 67.834 & 89.757 & 257.023 & 13.54 & 23.712 \\
\hline CSAP & 7.266 & 43551 & 64.602 & 716.323 & 1.373 .520 & 1.817 .419 & 5.204 .257 & 274.238 & 157.239 \\
\hline HERO & 81.126 & 300.830 & 194.083 & 811.414 & 2.219 .961 & 2937.416 & 8.411 .418 & 433.239 & 7.151 \\
\hline KON & 144 & 14303 & 179.670 & 58.573 & 316.146 & 418.319 & 1.197 .875 & 63.122 & 60.346 \\
\hline LPPF & 801.465 & 8327.700 & 49.981 & 318.271 & 1.683 .230 & 2.227 .222 & 6.377 .74 & 336.075 & $(150.036)$ \\
\hline MAPI & 319,492 & 354.228 & 267.119 & 889.299 & 2.338 .449 & 3.094 .859 & 8.862 .262 & 466.997 & 91.442 \\
\hline MPPA & 24.308 & 2.993 .996 & 270.121 & 2.274 .840 & 2.984 .553 & 3.949.111 & 11.308 .450 & 595.898 & 283.763 \\
\hline RALS & 19.307 & 864.109 & 17.979 & 1.382 .303 & 784.468 & 1.037 .995 & 2.972 .344 & 156.628 & $(236.250)$ \\
\hline RIMO & 190 & 227 & 93 & 723 & 5.806 & 7.682 & 21.998 & 1.159 & (53.353) \\
\hline SONA & 4.847 & 238.027 & 26.033 & 180.808 & 198.440 & 262.572 & 751.886 & 39.621 & (65.621) \\
\hline TRI0 & 24.710 & 242.548 & 1.277 .870 & 780.268 & 2860.131 & 3.784 .478 & 10.837 .014 & 571.056 & $(76.456)$ \\
\hline Industri & 134.609 & 506.526 & 265.661 & 712.762 & 1.457 .810 & 1.928 .950 & 5.523 .632 & 291.068 & \\
\hline
\end{tabular}

Sesuai dengan tujuan dari penerapan goal programming model dengan menggunakan target industri untuk mengetahui kinerja manajemen modal kerja masing perusahaan sampel terhadap industri, maka yang perlu dicermati dalam Tabel di atas adalah kolom Opportunity Cost. Pada perusahaan yang menghasilkan opportunity cost/loss bernilai positif (+), maka modal kerja perusahaan tersebut masih belum efisien. Sebaliknya, perusahaan yang menghasilkan opportunity cost/loss bernilai negatif (-), maka modal kerja perusahaan dapat dikatakan sudah efisien daripada solusi modal kerja yang ditargetkan berdasarkan hasil goal programming model.

Jika dicermati dari ringkasan hasil solusi di atas, PT Matahari Putra Prima Tbk (MPPA) menghasilkan nilai opportunity yang menge- jutkan sebesar 283.763 (tertinggi). Hal ini mengindikasikan bahwa berdasarkan target rasio yang diusulkan, MPPA masih dapat menambah rata-rata laba bersih sekitar Rp 283,7miliar. Jumlah ini tentu sangat tinggi jika dibandingkan nilai opportunity cost dari perusahaan yang lain dari Tabel di atas. Berdasarkan hasil solusi yang sesuai dengan target rasio industri yang diusulkan, maka proporsi rata-rata tingkat modal kerja selama tahun 2009-2013 yang dihasilkan oleh MPPA dapat dikatakan belum efisien dibandingkan tingkat modal kerja industri.

Sedangkan PT Ace Hardware Indonesia Tbk (ACES) mencatatkan hasil yang berbeda. Pada hasil di atas, opportunity cost yang dihasilkan ACES sebesar -358,444 (terendah). Hasil yang diperoleh ACES tersebut mencerminkan bahwa rata-rata proporsi modal kerja yang digunakan selama tahun 2009-2013 dapat dikatakan sudah efisien daripada rata- rata modal kerja industri.

Dari hasil opportunity loss, terdapat 7 perusahaan yang memiliki nilai opportunity loss positif. Ketujuh perusahaan ritel tersebut adalah AMRT, CENT, CSAP, HERO, KOIN, 
MAPI, dan MPPA. Hal ini mencerminkan bahwa rata-rata modal kerja yang digunakan oleh ketujuh perusahaan ritel tersebut selama tahun 2009 sampai 2013 kurang optimal dibandingkan dengan solusi target modal kerja yang diusulkan. Hal ini berarti hipotesis penelitian untuk ketujuh perusahaan tersebut diterima, yakni dengan menerapkan manajemen modal kerja yang dipertimbangkan, trade off likuiditas dan profitabilitas diperoleh hasil yang optimal. Disamping itu, terdapat 6 perusahaan ritel yang menghasilkan nilai opportunity loss negatif. Keenam perusahaan tersebut adalah ACES, LPPF, RALS, RIMO, SONA, dan TRIO. Rata-rata modal kerja yang digunakan keenam perusahaan ritel tersebut selama tahun 2009 sampai 2013 dapat dikatakan sudah optimal dibanding dengan target modal kerja yang diusulkan. Hal ini berarti hipotesis penelitian untuk keenam perusahaan tersebut ditolak, yakni dengan menerapkan manajemen modal kerja yang dipertimbangkan, trade off likuiditas dan profitabilitas tidak diperoleh hasil yang optimal.

Pada hasil penelitian ini sejalan dengan penelitian Deloof (2003) yakni profitabilitas dapat ditingkatkan dengan mengurangi inventori. Sejalan dengan penelitian Dash dan Hanuman (2009) bahwa modal kerja perusahaan tersebut belum optimal. Berdasarkan target yang ditetapkan peneliti, nilai opportunity cost yang positif mencerminkan adanya tingkat laba yang hilang dari modal kerja yang digunakan oleh perusahaan tersebut. Hal ini mengindikasikan bahwa sebenarnya modal kerja yang digunakan perusahaan tersebut masih dapat menghasilkan tingkat laba yang lebih besar dibandingkan dengan laba riil yang dicatatkan perusahaan tersebut pada tahun yang diteliti.

Namun hal ini bertentangan penelitian yang dilakukan oleh Panigrahi (2013) bahwa modal kerja negatif menunjukkan non- likuiditas atau kurang likuid dalam perusahaan tidak diinginkan pada setiap tahapan bisnis. Pada penelitan ini bahwa modal kerja yang negative belum tentu perusahaan itu tidak likuid, hal ini dikarenakan dengan penggunaan hutang dalam pengelolaan modalnya perusahaan dapat memperoleh tingkat perputaran modal yang cepat atau tinggi, hal ini dapat dilihat pada perusahaan PT Hero Supermarket Tbk (HERO), yang artinya dengan penggunaan utang untuk modal kerjanya perusahaan dapat memperoleh laba perusahaan. Dengan penggunaan utang untuk pembiayaan modalnya dapat mengurangi pembayaran pajak pada perusahaan.

\section{KESIMPULAN}

Dari hasil pembahasan diatas, maka dapat ditarik kesimpulan sebagai berikut :

a. Tingkat modal kerja perusahaan ritel selama tahun 2009-2013. Modal kerja yang digunakan oleh tiap perusahaan ritel pada tahun 2009 hingga 2013 sangat bervariasi. Dari hasil yang dicatatkan ketiga belas perusahaan ritel yang menjadi sampel, terdapat dua jenis modal kerja yaitu modal kerja positif dan negatif. Jika modal kerja perusahaan yang dicatatkan bernilai negatif, ini mengindikasikan bahwa perusahaan tersebut memanfaatkan hutang dalam membiayai operasionalnya. Ada 9 perusahaan yang mencatatkan jumlah modal kerja bernilai positif (ACES, CENT, CSAP, KOIN, MAPI, MPPA, RALS,SONA dan TRIO), dan ada 4 perusahaan yang mencatatkan modal kerjanya bernilai negatif (AMRT, HERO, LPPF, RIMO). Berdasarkan hasil rata-rata modal kerja industri (sebesar Rp 405,2 miliar), ditemukan 5 perusahaan ritel yang menggunakan modal kerja di atas rata-rata industri. Kelima perusahaan ritel tersebut adalah ACES, MAPI, MPPA, RALS dan TRIO. Disamping itu, ada 8 perusahaan ritel yang mencatatkan modal kerja dibawah rata-rata industri. Kedelapan perusahaan ritel tersebut adalah AMRT, CENT, CSAP, HERO, KOIN, LPPF, RIMO, dan SONA. Working capital rata- rata perusahaan ritel sebesar Rp405,2 miliar dengan rata-rata rasio working capital turnover sebesar 13,6 kali. Dari hasil tersebut, terdapat fenomena yang menarik terkait modal kerja dan penjualan yang dihasilkan tiap perusahaan ritel. Salah satu contohnya pada modal kerja yang dicatatkan oleh MPPA sebesar Rp1,6 triliun (terbesar daripada modal kerja perusahaan ritel lain) berada jauh diatas rata-rata modal kerja industri. Akan tetapi, perusahaan tersebut hanya menghasilkan total penjualan sebesar Rp 10,10 triliun sehingga perputaran modal kerjanya hanya mencapai 6,0 kali (jauh dibawah rata-rata perputaran modal kerja industri). Di sisi lain, AMRT 
mencatatkan modal kerja bernilai negatif sebesar -Rp703,7 miliar (paling kecil daripada perusahaan ritel lain) berada jauh dibawah rata-rata modal kerja industri. Dengan bermodal hutang sebesar yang disebutkan tersebut, AMRT mampu menghasilkan penjualan sebesar Rp 20,2 triliun (lebih tinggi daripada penjualan yang dihasilkan MPPA) dengan rasio perputaran modal kerja sebesar 28,7 kali yang berada jauh diatas rata-rata industri. Dari fenomena tersebut dapat disimpulkan bahwa pada 13 perusahaan ritel yang diteliti, jumlah modal kerja yang besar belum tentu menghasilkan total penjualan yang sepadan. Sebaliknya, jumlah modal kerja yang kecil belum tentu menghasilkan total penjualan yang kecil. Pada industri ritel modal kerja rata-rata perusahaan bernilai postif yang artinya perusahaan ritel sudah cukup efektif dalam pengelolaan modal kerjanya. Dalam artian perusahaan mampu memenuhi kewajiban lancar pada waktunya.

b. Tingkat likuiditas perusahaan ritel selama tahun 2009-2013. Tingkat likuiditas perusahaan ritel selama tahun 2009-2013.

c. Tingkat profitabilitas perusahaan ritel selama tahun 2009-2013 Rata-rata tingkat profit margin yang dihasilkan perusahaan ritel sebesar 0,05 atau $5 \%$. Terdapat perusahaan yang memi- liki tingat profit margin jauh lebih tinggi daripada rata-rata industri dan perusahaan dengan tingkat profit margin jauh dibawah rata-rata industri. RIMO mencatatkan profit margin sebesar 0,34 atau 34\% (jauh di atas rata-rata industri). Perolehan tersebut mencerminkan bahwa tingkat profitabilitas yang dimiliki RIMO sangat tinggi. Walaupun tingkat likuiditas yang dimiliki- nya jauh dibawah rata-rata industri, tetapi RIMO mampu menghasilkan tingkat profitabilitas yang tinggi. Berdasarkan hasil penelitian dicatatkan RIMO, maka tingkat likuiditas berbanding terbalik dengan tingkat profitabilitasnya. Hasil yang sama dicatatkan oleh CENT, Perusahaan tersebut mencatatkan profit margin sebesar -0,26 atau minus 26\% (jauh dibawah rata-rata industri). Hal ini mencerminkan bahwa tingkat profitabilitas yang diperoleh CENT kurang dari rata-rata industri. Dengan likuiditas yang cukup tinggi (sebesar 1,72 atau 172\%), tingkat profitabilitas yang diperolehnya juga lebih rendah dibanding rata-rata industri. Berdasarkan hasil yang diperoleh CENT, maka dapat disimpulkan bahwa tingkat likuditas perusahaan ritel berbanding terbalik dengan profitabilitas yang diperolehnya.

d. Aplikasi model trade-off likuiditas dan profitabilitas pada seluruh perusahaan ritelDari hasil opportunity loss, terdapat 7 perusahaan yang memiliki nilai opportunity loss positif. Ketujuh perusahaan ritel tersebut adalah AMRT, CENT, CSAP, HERO, KOIN, MAPI, dan MPPA. Hal inimencerminkan bahwa rata-rata modal kerja yang digunakan oleh ketujuh perusahaan ritel tersebut selama tahun 2009 sampai 2013 kurang optimal dibandingkan dengan solusi target modal kerja yang diusulkan. Hal ini berarti hipotesis penelitian untuk ketujuh perusahaan tersebut diterima, yakni dengan menerapkan manajemen modal kerja yang dipertimbangkan, trade off likuiditas dan profitabilitas diperoleh hasil yang optimal. Disamping itu, terdapat 6 perusahaan ritel yang menghasilkan nilai opportunity loss negatif. Keenam perusahaan tersebut adalah ACES, LPPF, RALS, RIMO, SONA, dan TRIO. Rata-rata modal kerja yang digunakan keenam perusahaan ritel tersebut selama tahun 2009 sampai 2013 dapat dikatakan sudah optimal dibanding dengan target modal kerja yang diusulkan. Hal ini berarti hipotesis penelitian untuk keenam perusahaan tersebut ditolak, yakni dengan menerapkan manajemen modal kerja yang dipertimbangkan, trade off likuiditas dan profi- tabilitas tidak diperoleh hasil yang optimal. Sedangkan dari hasil analisis Indonesia. http://aprindo.net/index.html (diunduh pada 17 September 2014)sensitifitas tiap variabel per perusahaan,. (2012). Peran Sektor Industri dapat ditarik kesimpulan bahwa tingkat kewajiban lancar dan jumlah aset tetap rata-rata perusahaan ritel memiliki elastisitas yang paling tinggi terhadap rata- rata perubahan tingkat laba bersih. Rekomendasi yang disarankan adalah setiap perusahaan ritel tersebut harus dapat mengontrol jumlah kewajiban lancar dan total aset tetapnya. Sedangkan sensitifitas variabel kas memiliki rata-rata elastisitas yang paling kecil terhadap rata-rata perubahan 
tingkat laba bersih. Tiap perusahaan ritel tersebut yang mengubah jumlah kas yang dimilikinya, maka tidak berdampak besar terhadap perubahan laba bersih yang diperolehnya.

\section{DAFTAR PUSTAKA}

Adhitia, Rezki; Manurung, Adler Haymans. (2009). "Analysis of Indonesia Bond's Duration: Corporate Versus Govern- ment Bond". Journal of Applied Finance and Accounting. Vol. 1 No. 2 June 2009, Page 328-338. Binus Business School, Jakarta.

Alagathurai, Ajanthan. (2013).Working Capi- tal Management (WCM) and Corpo- rate Profitability (CP): A Study of Selected Listed Companies in Sri Lanka (August 15, 2013). Internatio- nal Journal Of Business \& Manage- ment, Vol. 1, No. 2. pp.1-17.

Al Shubiri, Faris Nasif. (2011) The Effect of Working Capital Practices on Risk Management: Evidence from Jordan (2011). Global Journal of Business Research, Vol. 5, No. 1, pp. 39-54.

Anomymous. (2010). Laporan Perekonomian Indonesia Tahun 2009. Direktorat Riset Ekonomi dan Kebijakan Moneter, Bank Indonesia. Jakarta. http://www.bi.go.id (diunduh pada 17 September 2014).

Asosiasi Pengusaha Ritel.(2011). Pertumbuhan Bisnis Ritel dalam Mendorong Pertumbuhan Ekonomi Nasional. Kementerian Perindustrian. http//:www.kemenperin.go.id (diunduh pada 26 September 2014).

Antariksa, Riki (2008). "Pengaruh risiko likuiditas terhadap profitabilitas pada PT Bank Muamalat Indonesia." Eksis Jurnal Ekonomi Keuangan dan Bisnis Islami Vol.2 No.2 April-Juni. Halaman 120.

Arinkunto, S. (2006). Prosedur Penelitian Suatu Pendekatan Praktis. Edisi revisi VI. PT Rhineka. Jakarta.

Arinkunto, S. (2007). Dasar-Dasar Evaluasi Pendidikan, edisi revisi. Bumi Akasa- ra. Jakarta.

Berman B, Evans. (2004). Retail Manage- ment: A strategic approach. 9th ed. Pearson Education, Inc. New Jersey.

Brigham, EF,Houston, JF. (2006). Dasar- dasar Manajemen Keuangan. Edisi ke-10. Salemba Empat. Jakarta.

Dash, M; Hanuman, R. (2009). "A liquidity- Profitabilitby trade-off model for working capital management" Finance India. Vol. 2, Issue 2. Pp.1-10. http://papers.ssrn.com (diunduh pada 12 September 2014)

Djarwanto, (2004). Pokok-pokok Analisa Laporan Keuangan. Badan Penerbit Fakultas Ekonomi Yogyakarta. Yogya- karta.

Gilbert, David. (2003). Retail Marketing Management. 2nd edition. Prentice Hall. England.

Gitman.L.J. (2006). Principles of Managerial Finance. 10th edition. Prentice Hall. England.

Hanafi, Mamduh M. (2005). Analisa Laporan Keuangan. UPP AMP YKPN. Yogya- karta.

Hendri, Ma'ruf (2005). Pemasaran Ritel. PT Gramedia Pustaka Utama. Jakarta. 